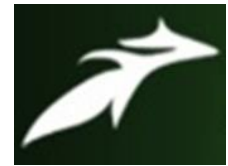

Varalakshmi. G et al, International Journal of Advances in Agricultural Science and Technology,

Vol.7 Issue.11, November-2020, pg. 9-15

ISSN: 2348-1358

Impact Factor: 6.057

NAAS Rating: 3.77

\title{
Effect of Incorporation of Moringa Leaf Meal at Varying Levels on Serum Biochemical Profile in Japanese Quail Diets
}

\author{
Varalakshmi. $\mathbf{G}^{1}$; Raja Kishore. $\mathrm{K}^{2 *}$; Srinivas Kumar. $\mathrm{D}^{3}$; Venkata Seshaiah. $\mathrm{Ch}^{4}$ \\ ${ }^{1}$ Post graduate Student, Department of Animal Nutrition \\ ${ }^{2}$ Assistant Professor, Department of Animal Nutrition \\ ${ }^{3}$ Professor and Head, Department of Animal Nutrition \\ ${ }^{4}$ Professor and Head, Department of Livestock Farm Complex \\ NTR College of Veterinary Science, Gannavaram \\ Sri Venkateswara Veterinary University, Tirupati, Andhra Pradesh, India \\ *Corresponding Author's Email: dr_rajakishore@yahoo.co.in \\ DOI: 10.47856/ijaast.2020.v07i11.002
}

\begin{abstract}
An experiment was conducted to study the effect of moringa leaf meal (MLM) at varying levels in the diet of quails on serum biochemical profile. One hundred and fifty day old quail chicks were randomly allotted into 5 experiment groups (T1, T2, T3, T4 and T5) each with 3 replicates of 10 chicks. MLM was incorporated at 0, 1.5, 3.0, 4.5 and $6.0 \%$ levels, respectively, in the different experimental groups. All the diets formulated were iso-caloric and iso-nitrogenous. At the end of the experiment, blood was collected from 2 birds/ replicate, thus a total of 30 birds and serum was separated. Results revealed that the albumin, calcium and phosphorus contents were increased $(p<0.05)$, while glucose decreased $(p<0.01)$ with increase in the level of MLM for 0 to $6.0 \%$ in the diet. And the values for total protein and globulin increased ( $p>0.05)$, while triglycerides, total cholesterol and creatinine decreased ( $>00.05)$ with linear increase of MLM in quail diets. Further, increase $(\mathrm{p}<0.05)$ in HDL Cholesterol level and decrease $(\mathrm{p}>0.05)$ in LDL and VLDL Cholesterol levels were recorded in serum with increased level of inclusion of MLM from 0 to $6.0 \%$ in the diet. The present study indicated that moringa leaf meal can be included up to $6.0 \%$ level in the diet of quails for production of low cholesterol meat without any adverse effects on production performance.
\end{abstract}

Keywords: Moringa leaf meal, Quails, Serum Biochemical profile, Cholesterol

\section{Introduction}

Commercial quail farming is becoming popular in the recent years in most of the Asian countries. Quail farming is economically viable and technically feasible because quails are quite resistant to various diseases, early sexual maturity (6 weeks of age) and easily adapt to various rearing conditions. Quail meat and egg are known for their high-quality protein, high biological value and low caloric content. Quail eggs are rich in essential minerals, vitamins and the nutritional value is three to four times greater than chicken eggs. Quail meat is reported to be tastier than chicken and promotes body and brain development in children (RSPCA, 2011). Poultry production sectors in developing countries are facing many problems, one of which is an increase in the cost of feed due to high prices of protein and energy sources. This also exerts impact on quail farming. The high and increasing prices especially of protein and energy ingredients for animal feeds have compelled researchers to direct their attention to cheap, available and safe alternative sources such as non-conventional feed sources. One possible source of protein is the leaf meal of tropical legumes. Leaf meals serve as source of protein and also provide some necessary vitamins, minerals and oxycarotenoids (D'Mello et al., 1987). One such nonconventional feedstuff, which could be of value for poultry feeding, is the leaves of Moringa.

Moringa oleifera is a tree with many uses and of great economic importance, widely available in most of the tropics. Every part of the Moringa oleifera tree, from the roots to the leaves has beneficial properties, which are used as fodder, herbal medicine, spices, food, natural coagulants, nectar to bees, fuel and fertilizer. 


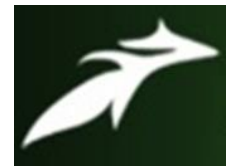

Varalakshmi. G et al, International Journal of Advances in Agricultural Science and Technology, Vol.7 Issue.11, November-2020, pg. 9-15

Moringa contains very high antioxidants and anti-inflammatory compounds (Yang et al., 2006). The leaves, flowers and pods are used as good sources of vitamins A, B and C, riboflavin, nicotinic acid, folic acid, pyridoxine, ascorbic acid, beta-carotene, calcium, iron, and alpha-tocopherol (Dahot, 1988). The antioxidant effect of Moringa oleifera leaf extract and fruit was due to the presence of polyphenols, tannins, anthocyanin, glycosides, and thiocarbamates, which remove free radicals, activate antioxidant enzymes, and inhibit oxidases (Luqmanet al., 2012). One important index of nutritional value of feeds is the haematological analysis as there is a positive correlation between protein quality and levels of haematological variables in the blood (Ufele and Ebenebe, 2017). This gives a good indication of the health status and physical condition of the birds and helps to differentiate apparently healthy birds from abnormal or diseased ones. Hence, the present work was conducted to study the effect of incorporation of moringa leaf meal at varying levels on serum biochemical profile in quail diets.

\section{Materials and Methods}

One hundred and fifty day old quail chicks were procured and randomly allotted into 5 groups each with 3 replicates of 10 chicks. Chicks were wing banded and weight of the chick was recorded. The experiment was carried out for 5 weeks in a completely randomized design (CRD). During the experiment, moringa leaves were ground and was included at 0\% (Control, T1), 1.5\% (T2), 3.0\% (T3), 4.5\% (T4) and 6.0\% (T5) levels in diets. All the diets were iso-caloric and iso-nitrogenous. The quail diets were formulated according to NRC, 1994 specifications. All the chicks were housed in battery brooders under uniform management conditions. Feed and water were provided ad libitum. At the end of the trial ( $5^{\text {th }}$ week $)$, two birds per replicate and thus a total 6 birds per treatment were randomly selected, weighed and slaughtered. Blood was collected from each bird (total of 30 birds) and serum was separated. Serum biochemical parameters like total protein, albumin, globulin, glucose, triglycerides and total cholesterol, various other forms of cholesterol, creatinine, calcium and phosphorus were estimated by using diagnostic kits (M/s. Span Diagnostics Private Limited). All the feed samples were analysed for proximate principles (AOAC, 2007) and cell wall constituents (Van soestet al., 1991). Statistical analysis of the data was carried out according to the procedures suggested by Snedecor and Cochran (1993).

\section{Results and Discussion}

The ingredient and chemical composition of diets formulated by incorporating moringa leaf meal (MLM) at varying levels and fed to Japanese quails in the present study was shown in Table 1. The diets were iso-nitrogenous and iso-caloric with a protein energy ratio of 1:121, by using ingredients like maize, DORB, soybean meal, fish meal and moringa leaf meal as per NRC, 1994 specifications. The effect of inclusion of MLM at varying levels in the diet on serum biochemical profile of quails was shown in Table $2 \& 3$.

\subsection{Serum Total Protein}

Inclusion of MLM up to $6.0 \%$ in the diet increased ( $\mathrm{p}>0.05)$ serum total protein content $(\mathrm{g} / \mathrm{dl})$ of quails (Table 2). These results corroborated with the findings of Zanu et al. (2012) who reported that inclusion of MLM in the diet had no effect $(\mathrm{p}>0.05)$ on serum total protein concentration in broilers. Similar findings were also reported earlier (Aderinola et al., 2013; Makanjuola et al., 2014) in broiler chicks. However, significant increase in serum total protein concentration was reported in broilers (Tesfaye et al., 2013; Hassan et al., 2016) and in quails (Elkloubet al. (2015) upon feeding higher levels of MLM compared to the control.

\subsection{Serum Albumin}

A significant increase $(\mathrm{p}<0.05)$ in serum albumin content $(\mathrm{g} / \mathrm{dl})$ was observed with incorporation MLM from 0 to $6.0 \%$ in the diet of quails (Table 2). Corroborating the results of the present study, Mousa et al. (2017) reported increased $(\mathrm{p}<0.05)$ serum albumin content in broiler chicks with inclusion of MLM at $1.5 \%$ level in the diet as compared to the control. In contrast, Lateef et al. (2016) reported that inclusion of MLM at 5, 10, 15 and $20 \%$ level in the diet has decreased $(\mathrm{p}<0.05)$ the serum albumin content in broilers as compared to the control. Elkloubet al. (2015) also reported similar findings in Japanese quail. On the other hand, El-Tazi and Tibin (2014) and Abou-Sekken (2015) reported no effect ( $p>0.05)$ on serum albumin content in broilers fed varying levels of MLM in the diet. 


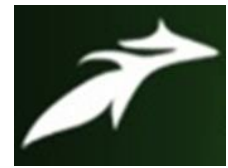

Varalakshmi. G et al, International Journal of Advances in Agricultural Science and Technology, Vol.7 Issue.11, November-2020, pg. 9-15

\subsection{Serum Globulin}

The present study revealed no effect $(\mathrm{p}>0.05)$ on serum globulin content $(\mathrm{g} / \mathrm{dl})$ of quails fed diets containing MLM from 0 to $6.0 \%$ (Table 2). In line with the present findings, Aderinola et al. (2013) reported that the inclusion of MLM up to $2.0 \%$ level in the diet of broiler chicks had no effect ( $p>0.05$ ) on serum globulin content as compared to the control. Similarly, Makanjuola et al. (2014) also reported that inclusion of MLM at $200 \mathrm{~g}, 400 \mathrm{~g}, 600 \mathrm{~g} / 100 \mathrm{~kg}$ in the diet had no effect $(\mathrm{p}>0.05)$ on serum total globulin concentration in broiler chicks. Further, increased ( $<<0.05)$ serum globulin content in broilers (Hassan et al., 2016; Mousa et al., 2017) was also reported.

Total plasma protein, albumin and globulin has been reported as an indication of the protein retained in the animal body (Akinola and Abiola, 1991). The relatively greater total plasma proteins of quails receiving dietary MLM might be an indication of the good protein content and/or quality of the leaf meal (Elkloub et al., 2015) which indicates that the immunity of the birds fed different levels of MLM was improved compared to the control group.

\subsection{Serum Glucose}

The serum glucose content $(\mathrm{mg} / \mathrm{dl})$ significantly decreased $(\mathrm{p}<0.01)$ with increased levels of MLM from 0 to $6.0 \%$ in the diet of quails (Table 3). These results are in agreement with the findings of Abou-Sekken (2015) who reported that supplementation of MLM at 5\% level resulted in decreased $(\mathrm{p}<0.05)$ serum glucose concentration in broiler chicks as compared to control. The reduction in serum glucose content observed upon MLM inclusion in the diet may be attributed to the insulin releasing and insulin like activity of MLM. In contradiction to these findings, Elkloubet al. (2015) reported increased $(\mathrm{p}<0.05)$ serum glucose content in quails.

\subsection{Serum Triglycerides}

Inclusion of MLM at varying levels from 0 to $6.0 \%$ in the decreased $(p>0.05)$ serum triglyceride content $(\mathrm{mg} / \mathrm{dl})$ in quails (Table 3). These results are in agreement with the findings of Bolu et al. (2013), who reported that the inclusion of MLM up to 7.5\% levels in the diet of broiler chicks had no effect ( $>>0.05)$ on serum triglyceride concentration as compared to the control. Similarly, Alnidawi et al. (2016) also reported that the inclusion of MLM up to $20 \%$ level in the diet of broiler chicks had no effect ( $>0.05$ ) on serum triglyceride concentration. On the other hand, decreased $(\mathrm{p}<0.05)$ serum triglyceride content in broilers upon feeding MLM in the diet were also reported earlier (Divya et al., 2014; Mousa et al., 2017). The decreased serum triglyceride content observed in quails fed diets containing MLM might be attributed to its hypolipidaemic effect.

\subsection{Serum Total Cholesterol}

The serum total cholesterol content $(\mathrm{mg} / \mathrm{dl})$ decreased $(\mathrm{p}>0.05)$ in quails fed varying levels of MLM from 0 to 6.0\% (Table 3). Similar findings were reported by Bolu et al. (2013) in broilers fed diets containing MLM at 0, 2.5, 5 and 7.5\%. Similarly, Gakuya et al. (2014) and Alnidawi et al. (2016) reported that the inclusion of MLM in the diet of broilers had no effect ( $p>0.05$ ) on serum total cholesterol content. On the other hand, significantly decreased serum total cholesterol content in broiler chicks (Abou-Sekken, 2015; Mousa et al., 2017) and in Japanese quails (Elkloub et al., 2015) were also reported. The decrease in the serum cholesterol levels observed in the present study could be attributed to the incorporation of MLM in the diet might had reduced the activity of 3-enzyme-3-methylglutaryl CoA (HMG-CoA) in the liver which is the key regulatory enzyme in cholesterol synthesis. Further, MLM increases the concentration of hepatic and faecal bile acids and neutral sterols which resulted in increasing hepatic degradation of cholesterol (Ghasi et al., 2000).

\subsection{Serum HDL Cholesterol}

The present study revealed increased $(\mathrm{p}<0.05)$ serum HDL cholesterol content $(\mathrm{mg} / \mathrm{dl})$ in quails fed diets containing varying levels of MLM from 0 to $6.0 \%$ (Table 3). In line with the findings of the present study, Abou-Sekken (2015) reported that inclusion of MLM at 5\% level in the diet resulted in increased ( $<<0.05)$ serum HDL cholesterol content in broilers. Similarly, Elkloub et al. (2015) reported increased $(\mathrm{p}<0.01)$ serum HDL cholesterol content in Japanese quails fed diets containing MLM. On the other hand, Gakuya et al. (2014) and Alnidawi et al. (2016) reported no effect ( $\mathrm{p}>0.05$ ) on serum HDL cholesterol content in broilers fed MLM diets. The increased serum HDL content observed in quails upon feeding MLM in the diet might be due to the significant hypo-lipidaemic effect resulting in lowering the total cholesterol levels and triglycerides and thus increasing the levels of high-density lipoprotein (Anwar et al., 2007). 


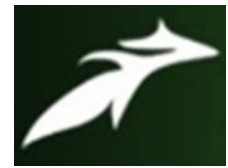

Varalakshmi. G et al, International Journal of Advances in Agricultural Science and Technology, Vol.7 Issue.11, November-2020, pg. 9-15

\subsection{Serum LDL Cholesterol}

The serum LDL cholesterol content $(\mathrm{mg} / \mathrm{dl})$ decreased linearly $(\mathrm{p}>0.05)$ in quails fed diets containing varying levels of MLM from 0 to $6.0 \%$ (Table 3). The results of the present study are in agreement with the findings of Gakuya et al. (2014) who reported that inclusion of MLM from 0 to $3.0 \%$ level in the diet of broilers had no effect $(\mathrm{P}>0.05)$ on serum LDL cholesterol content. Similarly, Alnidawi et al. (2016) reported that inclusion of MLM up to 20\% level in the diet had no effect ( $>0.05$ ) on serum LDL cholesterol in broilers. But, significantly decreased $(\mathrm{p}<0.05)$ serum LDL cholesterol content (Abou-Sekken, 2015) and in quails (Elkloub et al., 2015) was reported in broilers. The decreased serum LDL content observed in quails fed diets containing MLM might be attributed to enhanced hepatic bile acid synthesis and increased degradation of cholesterol to faecal bile acids and neutral sterols (Daba, 2016).

\subsection{Serum VLDL Cholesterol}

Inclusion of MLM up to $6.0 \%$ in the diet decreased (p>0.05) serum VLDL cholesterol content $(\mathrm{mg} / \mathrm{dl})$ of quails (Table 3). In line with the present findings, Alnidawi et al. (2016) reported that inclusion of MLM at 5, 10,15 and $20 \%$ levels in the diet had no effect $(\mathrm{p}>0.05)$ on serum LDL cholesterol in broilers. This might be attributed to the hypolipidaemic effects of MLM that enhanced hepatic bile acid synthesis and increased the degradation of cholesterol to faecal bile acids and neutral sterols.

\subsection{Serum Creatinine}

Inclusion of MLM at varying levels from 0 to $6.0 \%$ in the diet decreased ( $>>0.05$ ) serum creatinine content $(\mathrm{mg} / \mathrm{dl})$ in quails (Table 3). Creatinine is a waste molecule that is generated from protein metabolism. Reduction in creatinine formation indicates retarded catabolism rate in broilers (Divya et al., 2014). In contradiction to the present findings, Lateef et al. (2016) reported that supplementation of MLM up to $20 \%$ level in the diet resulted in increased $(\mathrm{p}<0.05)$ serum creatinine content in broilers as compared to the control. On the other hand, Divya et al. (2014) reported that inclusion of MLM up to $2.0 \%$ level resulted in decreased ( $<<0.05)$ serum creatinine content in broilers compared to control. Thus, decreased serum creatinine content observed in the present study indicates improved kidney health in terms of filtration rate which may be attributed to the incorporation of MLM in the diet.

\subsection{Serum Calcium and Phosphorus}

Inclusion of MLM from 0 to $3.0 \%$ level in the diet had no effect ( $>0.05$ ) on serum calcium and phosphorus content in quails as compared to the control. However, inclusion of MLM at 4.5 and $6.0 \%$ levels in the diet had increased $(\mathrm{p}<0.05)$ the serum calcium and phosphorus content as compared to the control (Table 3 ). The increased serum calcium and phosphorous level observed in the present study might be attributed to the higher levels of calcium and phosphorus present in MLM. Further, it reflects normal liver function of the birds fed diets containing MLM which also results in decreased plasma AST and ALT enzymes (Kaplan et al., 2003). In contradiction, Elkloub et al. (2015) reported that feeding MLM up to $0.6 \%$ in the diet decreased ( $<<0.01$ ) serum calcium and phosphorus content in Japanese quails.

\section{Conclusion}

The present study indicated that incorporation of moringa leaf meal up to $6.0 \%$ level in the diet had improved the good cholesterol content (HDLC) and reduced the total, LDL and VLDL cholesterol and triglyceride content in quails. Further, the antioxidant and anti-microbial property of moringa improved albumin and globulin content in quails which will help in enhancing immune system. Thus, it is concluded that moringa leaf meal can be incorporated up to $6.0 \%$ level in the diet of quails without any adverse effect.

\section{References}

[1] Abou-Sekken, M.S.M., 2015, Performance, immune response and carcass quality of broilers fed low protein diets contained either Moringa oleifera leaves meal or its extract. Journal of American Science. 11(6): 153-164.

[2] Aderinola, O.A., Rafiu, T.A., Akinwumi, A.O., Alabi, T.A. and Adeagbo, O.A., 2013, Utilization of Moringa oleifera leaf as feed supplement in broiler diet. International Journal of Food, Agriculture and Veterinary Science. 3(3): 94-102.

[3] Akinola, A.O. and Abiola, S.S., 1991, Blood chemistry and carcass yield of cockerels fed melon husk diets. Tropical Journal of Animal Science. 2: 39-44. 


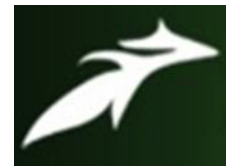

Varalakshmi. G et al, International Journal of Advances in Agricultural Science and Technology, Vol.7 Issue.11, November-2020, pg. 9-15

[4] Alnidawi, N.A., Hanaa, F.M., Sherein, S., Fatma, A. and Farid, M., 2016, Moringa oleifera Leaves in Broiler Diets: Effect on Chicken Performance and Health. Food Science and Quality Management. 58: 40-48.

[5] Anwar, F., Latif, S., Ashraf, M. and Gilani, A.H., 2007, Moringa oleifera: a food plant with multiple bio-chemical and medicinal uses. Phytotherapy Research. 21: 17-25.

[6] AOAC., 2007, Official methods of analysis (18th Ed). Association of Official Analytical Chemists, Washington DC.

[7] Bolu, S.A., Suleiman, F.F. and Adeyemi, K.D., 2013, Effect of Moringa oleifera leaf meal on the performance, haematology and serum biochemistry of broiler chickens. Niugini Agrisaiens. 5: 1-9.

[8] Daba, M., 2016, Miracle Tree:A review on multi-purposes of Moringa oleifera and its implication for climate change mitigation. Journal of Earth Science and Climatic Change. 7(8): DOI: 10.4172/2157-7617.1000366.

[9] Dahot, M.U., 1988, Vitamin contents of the flowers and seeds of Moringa oleifera. Pakistan Journal of Biochemistry. 21: $21-24$.

[10] D'Mello, J., Acamovic, T. and Walker, A.G., 1987, Evaluation of leucaena leaf meal for broiler growth and pigmentation. Trop. Agric. (Trinidad). 64: 33-35.

[11] Divya, Mandal, A.B., Biswas, A., Yadav, A.S. and Biswas, A.K., 2014, Effect of Dietary Moringa oleifera Leaves Powder on Growth Performance, Blood Chemistry, Meat Quality and Gut Microflora of Broiler Chicks. Animal Nutrition and Feed Technology. 14(2): 349-357.

[12].Elkloub, K., Moustafa, M.E.L., Riry, F.H., Mousa, M.A.M. and Hanan, A.H., 2015, Effect of using Moringa oleifera leaf meal on performance of Japanese quail. Egyptian Poultry Science Journal. 35: 1095-1108.

[13] El-Tazi S.M. and Tibin, I.M., 2014, Performance and blood chemistry as affected by inclusion of Moringa Oleifera leaf meal in broiler chicks diet. Journal of Veterinary Medicine and Animal Production. 5(2): 58-65.

[14] Gakuya, D.W., Mbugua, P.N., Kavoi, B. and Kiama, S.G., 2014, Effect of supplementation of Moringa oleifera leaf meal in broiler chicken feed. International Journal of Poultry Science. 13(4): 208-213.

[15] Ghasi, S., Nwobodo, E. and ofili, J.O., 2000, Hypocholesterolemic effects of crude extract of Moringa oleifera lam in high-fat diet fed Wester rats. Journal of EthanoPharmacology. 69: 21-25.

[16] Hassan, H.M.A., El-Moniary, M.M., Hamouda, Y., El-Daly, E.F., Youssef, A.W. and El-Azeem, N.A.A., 2016, Effect of different levels of Moringa oleifera leaves meal on productive performance, carcass characteristics and some blood parameters of broiler chicks reared under heat stress conditions. Asian Journal of Animal and Veterinary Advances. 11: 60-66.

[17] Kaplan, L.A., Pesce, A.J. and Kazmierczak, S.C., 2003, Liver function. In:Sherwin J.E. (Ed), Clinical Chemistry, fourth edition, Elsevier Science, St. Louis, Toronto.

[18] Lateef, T., Adetayo, A., Kudirat, A. and Murisiku, O., 2016, Effect of Moringa Leaf Meal Supplementation on Haematological and Serum Biochemical Profile of Broiler Chicken. Indian Journal of Animal Nutrition. 33(1): 75-80.

[19] Luqman, S., Srivastava, S., Kumar, R., Maurya, A.K. and Chanda, D., 2012, Experimental assessment of Moringa oleifera leaf and fruit for its antistress, antioxidant, and scavenging potential using in vitro and in vivo assays. EvidenceBased Complementary and Alternative Medicine. 2012: 1-12

[20] Makanjuola, B.A., Obi, O.O., Olorungbohunmi, T.O., Morakinyo, O.A., Oladele-Bukola, M.O. and Boladuro, B.A., 2014, Effect of Moringa oleifera leaf meal as a substitute for antibiotics on the performance and blood parameters of broiler chickens. Livestock Research for Rural Development. 26(8):1-4.

[21] Mousa, M.A., Osman, A.S. and Hady, H.A., 2017, Performance, immunology and biochemical parameters of Moringa oleifera and/or Cichorium intybus addition to broiler chicken ration. Journal of Veterinary Medicine and Animal Health. 9(10): 255-263.

[22] NRC. National Research Council. National Academy of Science. Nutrient Requirement of Poultry. 1994. (9th ed). Washington, USA.

[23] RSPCA. Royal Society for the Prevention of Cruelty to Animals. 2011, Quail: Good practice for housing and care. Research Animals Department. 4th edition. West Sussex RHI3 9RS. 2011, www. Rspca.org.uk/researchanimals.

[24] Snedecor, G.W. and Cochran, W.G., 1993, Statistical methods (9th edition) Iowa state university press, IOWA, USA.

[25] Tesfaye, E., Animut, G., Urge, M. and Dessie, T., 2013, Moringa olifera leaf meal as an alternative protein feed ingredient in broiler ration. International Journal of Poultry Science. 12(5): 289-297.

[26] Ufele, A.N. and Ebenebe, C.I., 2017, The effect of Moringa oleifera on the growth performance, packed cell volume (PCV) and laying capacity of young growing quails. American Journal of Zoological Research, 5(2), 33-37.

[27] Van Soest, P.J., Robertson, J.B. and Lewis, B.A., 1991, Methods for dietary fiber, neutral detergent fiber and non-starch polysaccharides in relation to Animal nutrition. Journal of Dairy Science. 74: 3583-3597.

[28] Yang, R., Chang, L.C., Hsu, J.C., Weng, B.B.C., Palada, M.C., Chadha, M.L. and Levasseur, V., 2006, Nutritional and functional properties of Moringa leaves - from Germplasm, to plant, to food, to health. Moringa and other highly nutritious plant resources: Strategies, standards and markets for a better impact on nutrition in Africa. Accra, Ghanawww.treesforlifejournal.org. Accessed 25th May, 2012.

[29] Zanu, H.K., Asiedu, P., Tampuori, M., Abada, M. and Asante, I., 2012, Possibilities of using moringa (Moringa oleifera) leaf meal as a partial substitute for fishmeal in broiler chickens diets. Online Journal of Animal and Feed Research. 2(1): 70-75. 


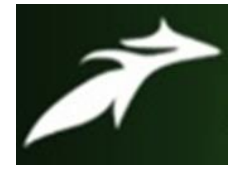

Varalakshmi. G et al, International Journal of Advances in Agricultural Science and Technology,

Vol.7 Issue.11, November-2020, pg. 9-15

ISSN: 2348-1358

Impact Factor: 6.057

NAAS Rating: 3.77

Table 1. Ingredient (\%) and chemical composition (\% DM basis) of quail diets.

\begin{tabular}{lccccc}
\hline \multicolumn{1}{c}{ Constituent/Diet } & T1 & T2 & T3 & T4 & T5 \\
\hline Maize & 50.00 & 48.67 & 47.67 & 46.33 & 45.33 \\
DORB & 8.67 & 9.00 & 9.67 & 10.33 & 10.67 \\
Soybean meal & 34.00 & 33.33 & 32.67 & 32.00 & 31.33 \\
Fish meal & 5.00 & 5.00 & 5.00 & 5.00 & 5.00 \\
Moringa leaf meal & 0 & 1.50 & 3.00 & 4.50 & 6.00 \\
DCP & 0.20 & 0.20 & 0.20 & 0.20 & 0.20 \\
Shell grit & 1.25 & 1.25 & 1.25 & 1.25 & 1.25 \\
Salt & 0.25 & 0.25 & 0.25 & 0.25 & 0.25 \\
Trace min mix & 0.15 & 0.15 & 0.15 & 0.15 & 0.15 \\
Feed additives & 0.55 & 0.55 & 0.55 & 0.55 & 0.55 \\
Total & 100 & 100 & 100 & 100 & 100 \\
ME ${ }^{*}$ Kcal/kg) & 2900.27 & 2900.51 & 2900.09 & 2900.17 & 2900.18 \\
Crude protein ${ }^{*}(\%)$ & 23.99 & 24.02 & 24.00 & 23.99 & 24.01 \\
\hline
\end{tabular}

Calculated value ${ }^{\#}$ Analyzed value

Table 2. Effect of dietary incorporation of moringa leaf meal at varying levels on serum total protein, albumin and globulins (g/dl)

\begin{tabular}{cccc}
\hline Treatment & Total protein & Albumin & Globulin \\
\hline T1 & $1.92 \pm 0.10$ & $1.16^{\mathrm{a}} \pm 0.02$ & $0.77 \pm 0.11$ \\
$\mathrm{~T} 2$ & $2.20 \pm 0.33$ & $1.27^{\mathrm{ab}} \pm 0.05$ & $0.93 \pm 0.33$ \\
$\mathrm{~T} 3$ & $2.32 \pm 0.31$ & $1.38^{\mathrm{bc}} \pm 0.15$ & $0.94 \pm 0.38$ \\
$\mathrm{~T} 4$ & $2.41 \pm 0.57$ & $1.46^{\mathrm{bc}} \pm 0.05$ & $0.95 \pm 0.57$ \\
T5 & $2.56 \pm 0.25$ & $1.55^{\mathrm{c}} \pm 0.03$ & $1.01 \pm 0.24$ \\
SEM & 0.15 & 0.04 & 0.15 \\
SS & $\mathrm{NS}$ & $*$ & $\mathrm{NS}$ \\
\hline
\end{tabular}

Values in column bearing different superscripts differ significantly $*(p<0.05)$

NS: Non-significant 


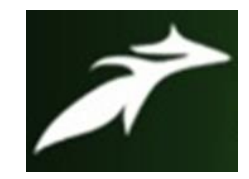

Varalakshmi. G et al, International Journal of Advances in Agricultural Science and Technology,

Vol.7 Issue.11, November-2020, pg. 9-15

ISSN: 2348-1358

Impact Factor: 6.057

NAAS Rating: 3.77

Table 3. Effect of dietary incorporation of moringa leaf meal on serum biochemical profile (mg/dl)

\begin{tabular}{|c|c|c|c|c|c|c|c|c|c|}
\hline Treatment & Glucose & Triglycerides & Total cholesterol & HDL-C & LDL-C & VLDL-C & Creatinine & Calcium & Phosphorus \\
\hline $\mathrm{T} 1$ & $259.11^{\mathrm{b}} \pm 9.98$ & $152.41 \pm 6.67$ & $211.80 \pm 4.42$ & $110.31^{\mathrm{a}} \pm 2.55$ & $71.01 \pm 4.78$ & $30.48 \pm 1.33$ & $0.67 \pm 0.16$ & $16.87^{\mathrm{a}} \pm 0.53$ & $5.74^{\mathrm{a}} \pm 0.27$ \\
\hline $\mathrm{T} 2$ & $245.78^{\mathrm{b}} \pm 14.14$ & $147.09 \pm 6.87$ & $209.00 \pm 2.41$ & $110.82^{\mathrm{a}} \pm 3.80$ & $68.03 \pm 6.10$ & $29.42 \pm 1.37$ & $0.63 \pm 0.09$ & $17.02^{\mathrm{a}} \pm 0.48$ & $6.56^{\mathrm{ab}} \pm 0.20$ \\
\hline $\mathrm{T} 3$ & $237.56^{\mathrm{b}} \pm 12.50$ & $145.34 \pm 6.90$ & $208.27 \pm 2.74$ & $114.18^{\mathrm{ab}} \pm 4.38$ & $65.02 \pm 7.12$ & $29.07 \pm 1.38$ & $0.56 \pm 0.10$ & $17.76^{\mathrm{ab}} \pm 0.36$ & $6.84^{\mathrm{ab}} \pm 0.05$ \\
\hline $\mathrm{T} 4$ & $228.22^{\mathrm{b}} \pm 6.85$ & $133.03 \pm 6.99$ & $204.99 \pm 4.17$ & $120.03^{\mathrm{ab}} \pm 3.52$ & $58.35 \pm 4.54$ & $26.61 \pm 1.40$ & $0.44 \pm 0.08$ & $18.96^{b c} \pm 0.30$ & $7.43^{b c} \pm 0.40$ \\
\hline $\mathrm{T} 5$ & $174.11^{\mathrm{a}} \pm 17.07$ & $131.50 \pm 5.62$ & $202.31 \pm 2.68$ & $125.58^{\mathrm{b}} \pm 4.13$ & $50.42 \pm 4.27$ & $26.30 \pm 1.12$ & $0.48 \pm 0.04$ & $19.55^{\mathrm{c}} \pm 0.74$ & $8.77^{c} \pm 0.90$ \\
\hline SEM & 7.54 & 3.15 & 1.53 & 1.89 & 2.65 & 0.63 & 0.04 & 0.29 & 0.27 \\
\hline SS & $* *$ & NS & NS & $*$ & NS & NS & NS & $*$ & $*$ \\
\hline
\end{tabular}

Values in column bearing different superscripts differ significantly $*(\mathrm{p}<0.05)$

$* *(\mathrm{p}<0.01)$

NS: Non-significant 